\title{
Efforts to Reduce Production Costs Bag Recycling on Waste Bank (Case Studies in Rw 01 Kecamatan Mekarsari Cimanggis Depok)
}

\author{
Erni Prasetiyani ${ }^{1}$, Martina Safitry ${ }^{2}$, Ai Nety Sumidartini ${ }^{3}$ \\ \{erani@stiami.ac.id ${ }^{1}$, martinasafitry75@gmail.com², answara06@yahoo.com³ \\ Institut Ilmu Sosial dan Manajemen Stiami, Jakarta, Indonesia ${ }^{1,2,3}$
}

\begin{abstract}
The objectives of this activity are: 1). Creating new methods in an effort to reduce the costs of producing recycled bags produced, and 2). Making Waste Bank a sustainable business entity and contributing to the welfare of its customers in this case the surrounding community. The following are conclusion from the results of Community Service : 1). During this time Waste Bank Sehati produces bags involving external parties (maklon services) tailor bags to complete the final process of the bag after the basic woven bag is formed in a unit, so the production price becomes expensive, 2). Waste Bank Sehati has not fully implemented the standard production system and 3). Waste Bank Sehati didn't activists to reduce production costs. After community service implemented at the Waste Bank Sehati , for the sake of the progress of the Waste Bank Sehati we recommend: Production planning must be arranged from the input to the output produced, the procurement of bag sewing machines and the recruitment of workers with experience in the bag industry is the main key if Waste Bank Sehati wants to advance and develop in the recycling bag industry, and in order to become a sustainable center for the people's economy, Waste Bank Sehati should more innovative to product design, market segment, and marketing strategy.
\end{abstract}

Keywords: Waste Bank, Production Costs Reduction, People's Economic Center.

\section{Introduction}

One areas that is fairly fast growing Waste Bank is Mekarsari Village, Cimanggis SubDistrict. There are $13 \mathrm{RW}$ with 18 Waste Banks as follows 4 Waste Banks in RW 08, 2 Waste Banks in RW 12 and RW 01, the others are 1 Waste Bank.

From 18 (eighteen) existing Waste Banks, Community Service will be held at Waste Bank Sehati in RW 01. Waste Bank Sehati, one of the most active recycling collector activists, even has its own product in the form of bags made from coffee packaging waste. sachet. However, up to now the production of recycled bags has not been running as expected because of the high production costs constrained in the final production process. The production process according to Sofyan Assauri (2016: 123) is an activity that involves human resources materials and equipment to produce useful products. With the problem in the final process of finishing, this Community Service will provide solutions from several alternatives in an effort to reduce the cost of producing recycled bags. The targeted effect of the reduction in production costs is the selling price of recycled bags that are more affordable for the public. 
The formulation of Community Service Issues consists of: 1). How is the production process in Waste Bank so far ?, 2). Does Waste Bank implement a standard production system to produce recycled bags produced ?, and 3). What efforts have been made to reduce production costs?

The objectives of this activity are: 1). Creating new methods in an effort to reduce the costs of producing recycled bags produced, and 2). Making Waste Bank a sustainable business entity and contributing to the welfare of its customers in this case the surrounding community.

The benefits of activities for Implementing Activities and Academic Sections are: 1). Creating new methods in an effort to reduce the cost of producing recycled bags produced, 2). As a people's economic center, it is hoped that Waste Bank can prosper the customers of Waste Bank Sehati, 3). With the new production system both managers and customers can work together to advance Waste Bank Sehati, and 4). Introducing the Stiami Jakarta Institute campus to the surrounding community, arousing a sense of campus friendship with the community and building the image of the institution of the Stiami Institute campus to the people Depok around.

\section{Literature Study}

\subsection{Definition of Waste}

According many sources, the meaning of waste is, as follows: 1). Waste is objects that not functioning or no longer used, and 2). Waste is a wasted material that or materials useless of human activities and natural processes that do not have economic value. (Environmental Terms for Management, Ecolink, 1996).

\subsection{Waste management}

Waste management is the collection, delivered, processing, recycling, or disposal of waste material. Depok as the supporting city of DKI Jakarta is one of the destinations for Jakarta residents who want to get a decent and ecologically better place to live. Based on data obtained from the Population Office in Depok in its official portal www.depok.go.id in 2011 the population in Depok city was 1,667,000 people, in 2016 there were 2,142,464 people. This rapid increase in population has resulted in the need for supporting activities to reduce the growth and development of the volume of waste. One of them is the creativity of converting recycled waste into goods that have economic value, which in turn can improve the local micro-enterprise as a center of the people's economy.

According to Law Number 18 of 2008 concerning Waste Management along with Government Regulation Number 81 of 2012 mandating the need for a fundamental paradigm change in waste management, from the gathering-transport-waste paradigm to processing that relies on reducing waste and handling waste. This activity aims to reduce the volume of waste and Reduce, Reuse and Recycle (3R) on all elements of the community to reduce waste, meaning that all levels of society, individuals, government and legal entities (Reiza Fitri Yulia: 2014). 


\section{Implementation Method}

The implementation method is as follows: 1). Sehati Waste Bank Survey, 2). Survey of Tasikmalaya woven bag training ground, 3). Training at Priangan Craft (producer of pandanus woven bags, Tasikmalya), 4). Entrepreneurship training and product diversification, and 5). Determination of an efficient and effective production system.

\section{Results and Discussion}

\subsection{Sehati Waste Bank Survey}

The initial survey was carried out at the location of the Sehati Waste Bank Rw 01 Mekarsari Village, Cimanggis District, Depok City. Here recyclable waste is collected and then sent to collectors. While the coffee sachet waste which is the basic material for making bags is separated and valued at Rp. 500, - per kg.

This survey purpose to identify the problems faced by businesses making sachet coffee recycling bags. . The results of the field survey, the producers had not been able to finish the product. Product constraints are not finalized due to the following: 1). Experienced human resources sewing bags not available, and 2). They have not sewing machine facilities suitable for sewing bags.

Base on the Waste obstacles from the Waste Bank Sehati, the researcher bridged by providing training in a standard production process for bags that are unique. Unique because this product is made from recycled waste instead of leather or materials that are easily done with ordinary sewing machines. Because of the uniqueness of this product, the researcher recommends a study tour to a bag manufacturer made from pandan leaves and mendong rope in the Tasikmalaya area. With the aim of being able to open the insights of Waste Bank Sehati activists about the bag production process and the diversification strategy of the recycled bag model which has been produced by Waste Bank Sehati.

\subsection{Survey of Pandan Bag Tasikmalaya Production}

At this phase, the researchers put forward a production method that had been applied at the location of the traditional bag craft training center originating from pandan leaves and mendong ropes, namely Priangan Craft which is located at Sukaruas Village, Sukaraja Village, Sub district Rajapolah, Tasikmalaya. The survey results from Tasikmalaya are as follows: 1). The cost of production of pandanus bags is strongly influenced by the quality of the auxiliary material attached to the product and the presence of additional accessories. Example: standard zipper Rp. 2,000, - while quality zipper no. 1 Rp. 5,000, - Rp. 10,000.0 standard wooden bag strap Rp. 6,000, - quality wooden bag strap no. $1 \mathrm{Rp} \mathrm{10,000,-2).} \mathrm{Before} \mathrm{the} \mathrm{production} \mathrm{of} \mathrm{a}$ model a pattern is needed where this is not available at Waste Bank Sehati, 3). Use of highquality auxiliary materials and additional accessories tailored to the requests / orders from customers, 4). Raw materials and auxiliary materials are obtained from suppliers, meaning that Priangan Craft is a pure bag industry and does not produce its own raw materials. Raw materials supplied, namely: a). Pandan: from Serang for Rp. 100,000 / cody, b). From Gombong Central Java at a price of Rp. 300,000, - / cody, and c). Mendong: From Tasik Malaya, Yogya, Jember, East Java, 5). Labor is paid per product that has been produced and adjusted to the level of difficulty. The tariff for making a bag ranges from Rp. 7,000 to Rp. 
21,000 and 6). The products produced are very diverse according to the target market segment. For export segments and tourist destinations for foreign tourists (Bali, Lombok and Yogyakarta), all materials are of higher quality than for the domestic segment.

The description of the production process and post-production obtained from traditional bag craftsmen in Tasikmalaya is very suitable to be applied in Waste Bank Sehati.

\subsection{Tasikmalaya Training}

At this phase the research team and the core team Waste Bank Sehati (2 people) conducted a workshop with Priangan Craft craftsmen. Various kinds of skills from various aspects are obtained, including: 1). The production process, from making bag patterns to sewing bags, 2). Selection of raw materials and auxiliary materials tailored to market segments, and 3). Creating a bag that was monotonous and less attractive has become more varied and can be well received by the market.

\subsection{Entrepreneurship training and product diversification}

This training divided into 3 sessions, : 1). Introduction to Entrepreneurship, Giving materials tailored to the interests of trainees, and focusing on how to grow the entrepreneurial spirit to the participants. The themes raised in this session are: a). - Motto of entrepreneurship, b). Entrepreneurial characteristics, c). Read business opportunities, and d). Tips still exist in entrepreneurship, 2). Business Opportunities and Reduction of Recycling Bag Production Costs, The contents of the material presented in this session are: a). The potential for waste is a source of income for housewives, b). Waste recycling products that are sustainable and have high selling value, such as compost, stationeries made from used cardboard, c). Tips for sustainable business strategy, d). Determination of selling prices of recycled products, e). Calculation of production costs, f). Waste Bank Sehati production process system, and g). Alternative production process flow to reduce production costs.

\subsection{Newspaper Waste-Based Product Diversification Training}

The research team invited a trainer, a successful housewives being entrepreneurs who produced newspaper waste-based products and owned the brand "Dhara Handmade". In addition to adding waste-based skills, the researcher also aims to provide motivation to manage the business so that it still exists based on Wiwik's mother's experience. Participants were given basic engineering training to roll newspaper with a piece of bamboo. With the right technique, paper rolls are produced that are not easily changed. These processed products can be used as basic materials for various products such as: fruit plates, placemats, baskets and etc.

\subsection{Determination of an efficient and effective production system}

With these limitations, the researcher gives several alternatives and gives a financial picture of the alternative methods of bag production offered.

\subsection{The production process is fully carried out by Waste Bank Sehati}

To produce their own bags, Waste Bank Sehati must have a special sewing machine for bags and the investment of this machine ranges from IDR 4,000,000 to IDR 5,000,000 (market price). Production costs starting from the raw material for sachet coffee packs of Rp. 500, - / $\mathrm{kg}$. To complete the product until it becomes a bag that is ready to be sold to the final consumer, it is necessary to use indirect material as much as Rp. 12,000 / m2 (market price). 1 
meter can be used for 2 bags of $25 \mathrm{~cm}$, IDR 8,000 (market price), bag handles wood Rp. 7,500 (market price). The assumption of direct labor costs calculated per unit of bag produced is for weaving services and final settlement of Rp. 12,000. Overhead such as machine maintenance electricity and others Rp. 2,000, -.

Table 1. Calculation Illustrate

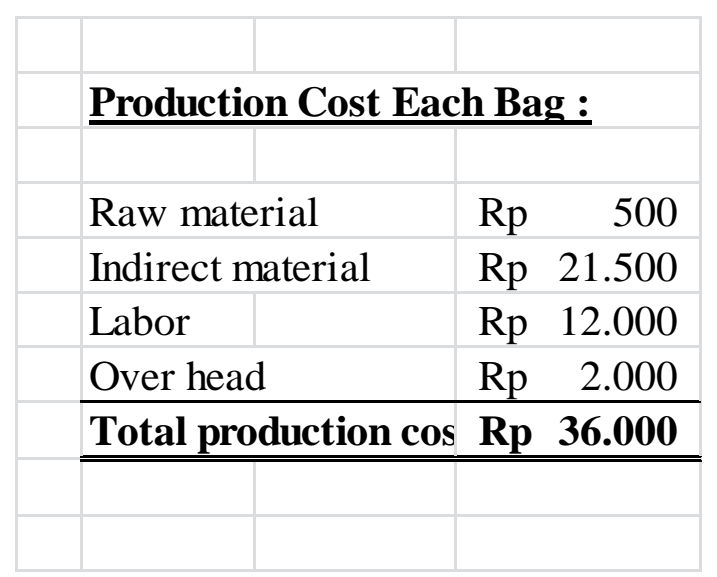

\subsection{Semi-finished production process, final completion with maklon}

A clone is giving orders to other parties who are more competent to do a job and then the work returns to the order giver.

Because of the limitations on the bag sewing machine, the second alternative is to make a maklon to complete the bag in bulk. A bag industry in Bogor gives a price of IDR 35,000 for a small bag and IDR 45,000 for a medium bag.

\section{Conclusion}

The following are conclusion from the results of Community Service : 1). During this time Waste Bank Sehati produces bags involving external parties (maklon services) tailor bags to complete the final process of the bag after the basic woven bag is formed in a unit, so the production price becomes expensive, 2). Waste Bank Sehati has not fully implemented the standard production system, parts of the system not yet exist include planning and production facilities such as sewing machine for bag not available, and 3). Waste Bank Sehati didn't activists to reduce production costs, Waste Bank Sehati still relies on maklon services to complete the final bag process if there is an order.

\section{Suggestion}

After community service implemented at the Waste Bank Sehati, for the sake of the progress of the Waste Bank Sehati we recommend: 1). Production planning must be arranged from the input to the output produced. By planning carefully recycled bag production becomes more effective and efficient. One goal is to minimize the cost of producing recycled bags2). 
The procurement of bag sewing machines and the recruitment of workers with experience in the bag industry is the main key if Waste Bank Sehati wants to advance and develop in the recycling bag industry, and 3). In order to become a sustainable center for the people's economy, Waste Bank Sehati should more innovative to: a). Product design, b). Market segment, and c). Marketing strategy.

\section{Acknowledgments}

Special thanks to the STIAMI Institute for funding this Community Service and to the Team of Lecturers and Waste Bank Sehati Team who have helped and supported the implementation of this Community Service to become a writing that can be a reference material to develop Waste Bank business in the future.

\section{Reference}

[1]. Ecolink. 1996. Pengertian dan Definisi Sampah Menurut para Ahli. 26 April 2012. http://tpasukawinatan.wordpress.com/2012/04/26/Pengertian-definisi -sampah-menurut-para-ahli.

[2]. Assauri, Sofjan. 2016. Manajemen Operasi Produksi. Edisi 3. Rajawali Pers. 123

[3]. Yulia, Reiza Fitri. 2014. Makalah Bank Sampah untuk Menghasilkan Uang. IAIN Syekh Nurjati Cirebon.

[4]. https://www.depok.go.id/24/02/2017/01-berita-depok/60-bank-sampah-solusi-atasi-sampah-disukmajaya 